UDC $[614+613.6]:[658.114 .5: 005]$

\title{
STRATEGIES FOR THE EVALUATION OF AN INTERNATIONAL RESEARCH CONSORTIUM: BEST PRACTICES
}

\section{Edison M.', Kozyclkyj T.2, Hryhorczuk, D. 0.1,2, Iwanik K.', Dardynskiy 0.', Dardynskaia I. 2 \\ 'Center for Global Health, University of Illinois College of Medicine, Chicago, USA 2School of Public Health, University of Illinois at Chicago, USA}

This paper reviews the literature in order to inform the creation and implementation of an evaluation plan that will assess an international research consortium.

Key words: international research consortium, program evaluation, logic model

\section{Introduction}

Collaboration among researchers across international borders has, with the growth of electronic methods for communications and sharing of data, blossomed beyond the wildest dreams of scientists. Networks can now easily focus on global health issues by developing consortia that bring research skills from many nations together.

As these collaborative efforts proceed, there is a need for two types of evaluation. Certainly there must be a focus on the scientific outcomes of the research projects undertaken by these consortia; each project can be assessed on the extent to which the stated objectives were met, as well as on the success of dissemination efforts and on future research activities. There is also a need to establish evaluation strategies to assess the success of the consortium itself; in this paper, we explore the efforts that have been made to evaluate research consortia.

\section{Background-Evaluation is important to NIH}

The University of Illinois at Chicago, in partnership with the Institute of Occupational Health; Marzeyev Institute for Hygiene and Medical Ecology; Institute for Pediatrics Obstetrics and Gynecology; Institute of Endocrinology and Metabolism; and Centers for Radiation Medicine; embarked on the planning for an international research consortium to address issues of Energy Security and Health Protection in Ukraine. Support for the planning of this Global Environmental and Occupational (GEO) Health Hub was provided by the U. S. National Institutes of Health Fogarty
International Center. Evaluation will be significant component of the GEO Health Hub going forward.

Global Health Research collaborations between universities in the United States and those in other countries have, for more than 40 years, been encouraged and supported by the Fogarty International Center (FIC), which was established as a department within the National Institutes of Health in 1968. In 2002, Fogarty's Division of International Science Policy, Planning, and Evaluation (DISPPE) developed a «Framework for Program Assessment (Evaluation and Review)» [1] to enable researchers to understand the agency's program evaluation process. This document, although designed to facilitate program planning in general, includes strategies that can and should be considered in the evaluation of research partnerships and consortia. The framework document identifies four areas that should be used to assess and document the effectiveness of FIC programs, and performance indicators that would be appropriate for each area.

Program Planning is an important step in the creation of a consortium. From an evaluation standpoint, it is crucial to document how the planning process was undertaken, the roles of stakeholders, and vision and goals that emerged.

Program Management encompasses many of the important functions of the consortium, such as project selection and recruiting talent. Specific evaluation questions would address the development of funding announcements, the composition and function of project review and selection committees, the role of the consortium project manager, the establishment of performance indicators for projects, and the 
monitoring of financial and human subjects regulations.

Partnerships and Communication are at the heart of a collaborative research center. FIC emphasizes the importance of selecting the right partners. The evaluation efforts will describe how the partners are chosen, and identify the strengths each brings to the consortium. Similarly, the methods for sharing information and the means of communications between the partners must be effective; this will be another focus of the evaluation.

Results of the Program requires an evaluation of the specific research projects undertaken by the consortium; outcomes to be assessed will not only include the extent to which project objectives were attained, but also examples of related research productivity such as publications, presentations, and awards received. In addition, it will be important to evaluate increased research capacity, as measured by the number of trainees completing degrees or advanced educational activities. Finally, it will be essential to assess the influence of projects on health policy and on ongoing health research.

FIC recognizes the importance of Program Assessment; all FIC funded projects are expected to conduct regular program evaluations and project reviews.

\section{Another Evaluation Framework for Research Consortia}

A team of researchers from the HMO Cancer Research Network (CRN) [2] have proposed a framework for evaluating multicenter consortia that can be applied to international collaborations as well. They developed an evaluation methodology that focused on five areas; participant surveys administered to over 500 administrative and scientific staff over a 5 -year period provided the data for analysis. The purpose of the evaluation was not only to assess outcomes, but also to provide formative feedback that could be used for ongoing quality improvement.

Extent of Collaboration and Quality of Communication. In this domain, surveys included questions that assessed the effectiveness of the Network Steering Committee, cooperation among research sites, and ease and quality of communications.

Performance of Projects and Infrastructure. Evaluation questions here focused on effectiveness of project leadership, organization, meetings, and within-project communications and group work.
Data Quality. Here again, the evaluation addressed the specific research projects; in particular, the processes for collecting, monitoring, and analyzing data.

Scientific Productivity. One important measure of success of a research collaboration is publications in peer-reviewed journals and presentations at national and international meetings. The evaluation process can elicit not only the numbers of these outcomes, but also the extent to which the consortium leadership has facilitated the creation of scholarship.

Impact on Member Organizations. In a research consortium, each partner has expectations for the achievements of the consortium as a whole, but also for their own organization. The evaluation must include an assessment of partner satisfaction, development of ongoing research relationships and projects, and enhancement of organizational reputation.

The resuits of the CRN evaluation identified «in-person contact; transparent decision-making processes; efficient use of communication modalities; and creating opportunities for all collaborators to play an active role in the consortium's research and operations» [2] as key indicators of success. A comprehensive evaluation that explores the domains identified by CRN researchers can provide valuable feedback to international research consortia.

\section{Recent Evaluation Studies of Research Collaborations}

Evaluation studies of research collaborations often focus on project outcomes, rather than on the collaborative process. Katsouyanni's 2008 article [3] reports numbers/percentages of internationally co-authored publications; results show a dramatic increase between 1985/86 and 1995/96. In the discussion, the author suggests a focus on evaluation that addresses the characteristics of collaborative research, as opposed simply to outcomes. Similarly, Maher's 2010 evaluation of the ALPHA network [4] provided extensive outcome data on specific projects and their research findings regarding collaborative research on HIV/AIDS in Africa, but no detailed description of the evaluation of the collaborative process is presented. Marjanovic (2013) presents a «real-time» evaluation strategy used in the African Institutions initiative [5]. The evaluation not only included a baseline assessment of each of the research 

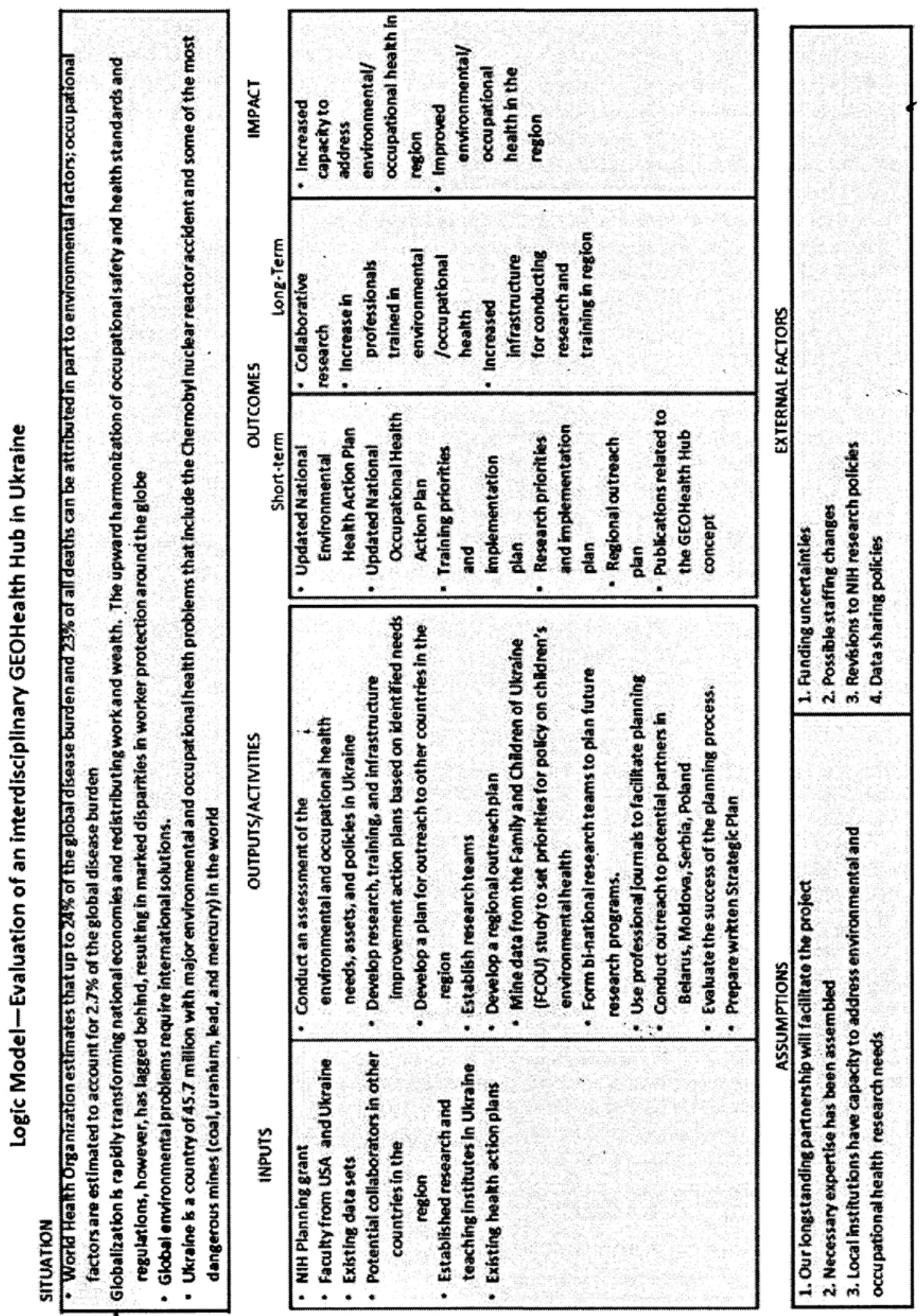

을 
partners to understand their management, governance, scientific skills, and human resources capacity, but also was followed up by evaluation workshops, teleconferences, email, and telephone interviews to collect data. Mayhew (2008) reported the results of an evaluation study conducted to assess a South Africa-Thailand-London research partnership [6]. In addition to determining the number of publications, workshops, and courses offered, this evaluation included semi-structured interviews that addressed some of the more process-oriented outcomes, such strengthening partnerships. A 2007 study that describes the Colombian Neonatal Research Network [7] includes some evaluation results categorized as «observed benefits of international collaboration» and «perceived barriers during the international collaborative effort»; some of the responses address the domains described earlier in this paper. However, little is said about the actual evaluation process; creation and purposes of research collaborations are more prevalent-not only in the medical and public health literature, but also in areas such as public affaits [8].

Overall, despite the presence of numerous theoretical models for program evaluation [9], most studies of research consortia evaluate whether specific objectives were met, rather than how they were met.

\section{Using a Logic Model for Evaluation}

The Logic Model, created as a tool for program planning in the 1970's, is now commonly used for program evaluation. It illustrates the relationship between program Inputs (what we invest), Outputs (including Activities, Participants Served); and Outcomes/Impacts (short, medium, and long term), all in the context of a particular situation. or environment.

In planning for the GEO Health Hub, we developed the Logic Model found in Figure.

\section{Discussion/Conclusions}

Evaluating the effectiveness of a global research consortium presents challenges. In general, the literature describing research collaborations is focused on the outcomes of the specific research projects undertaken by the consortium, and the consortium is considered effective if the individual projects are successful. This type of evaluation is certainly necessary, but not sufficient to address all the aspects of global research consortia. We would utilize focused questions and established evaluation techniques and methods to assess the effectiverfess of the consortium as a whole.

Formation of the consortium: partners; mission; and goals. One aspect of the evaluation will be to understand how the consortium came into being. An assessment conducted during the early stages of the development of the consortium will demonstrate the issues considered central to the mission of the consortium, the methods utilized to select partners, and the research goals.

Collaboration, communications, infrastructure, and management. Ongoing evaluation can be used to provide insights into the inner workings of the consortium. Stakeholders, including research partners and consortium staff, should be interviewed or surveyed on a regular basis in order to confirm that the systems and structures of the consortium are performing as they should. These formative evaluations may be used in continuous quality improvement efforts.

Project selection and implementation. Since the consortium will be judged, at least in part, on the success of the research projects it supports, an evaluation of the processes employed in the selection and implementation of these research projects will be needed. Once the projects have been identified and are underway, an evaluation of the project management, communications mechanisms, and infrastructure may be used to help in the monitoring function. At the end, an evaluation will be done to measure congruence between project objectives and results, and to display important visible outcomes such as publications and presentations.

Sustainability. Certainly one organizational mission of any gtobal multidisciplinary research consortium is to survive. In order to achieve this, the consortium must not only demonstrate success in its research efforts, but also prove that it is capable of securing additional funding to support ongoing projects. A comprehensive evaluation will provide the tools and information that can be used in sustainability efforts.

The importance of evaluation cannot be underestimated. Continuous improvement and long-term sustainability of global research consortia depend on high-quality, comprehensive evaluation efforts. 


\section{References}

1. Sturke, R. 2002, Framework for Program Assessment. Fogarty International Center Division of International Science Policy, Planning and Evaluation.

2. Greene, S., Hart, G., Wagner, E. 2005, «Measuring and improving performance in multicenter research consortia», $J$. of the National Cancer Institute Monographs, V. 35, pp. 26-32.

3. Katsouyanni, K. 2008, "Collaborative Research: accomplishments and potential", Environmental Health, V. 7, no. 3 .

4. Maher, D., Biraro, S., Hosegood,V. et al. 2010 , "Translating global health research aims into action: the example of the ALPHA network", Tropical Medicine and International Health, v. 15, no. 3, pp. 321-328.

5. Marjanovic, S., Hanlin, R., Diepeveen, S., Chataway, J. 2013, "Research Capacity-Building in Africa: networks, institutions, and local ownership", J. of international development, v. 25, pp. 936-946.

6. Mayhew, S., Doherty, J., Pitayarangsarit, S. 2008. "Developing healthy systems research capabilities though north-south partnership: An evaluation of collaboration with South Africa and Thailand", Health Research Policy and Systems, v. 8, no. 6.

7. Rojas, M., Lozano, J., Rojas, M. 2007, «International collaborative research: a Colombian model that promotes infant health and research capacity", J.of Perinatology, v. 27, pp. 738-743.

8. Vanda, D., Shoup, J., Miller S. 2012, "A Systematic Review of Collaboration and Network Research in the Public Affairs Literature: Implications for Public Health Practice and Research", American Journal of Public Health, v. 102, no. 3, pp. 564-571.

9. Frye, A., Hemmer, P. 2012, "Program evaluation models and related theories: AMEE Guide No. 67n, Medical Teacher, v. 34, pp. e288-e299.

\title{
ЕАісон М.', Козишький Т. ${ }^{2}$, Григорчук А. О.',2, Иваник К.', АарАинський О.', АарАинська И.2

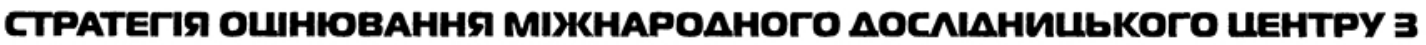

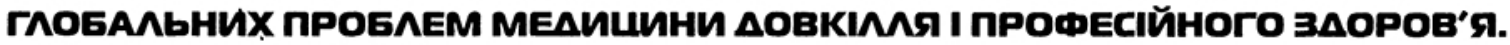

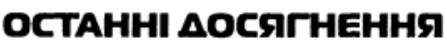

\author{
'Шентр глобального зАоров'я, Університет штату Імінойс, КолеАж медишини, Чікаго, США \\ ¿Школа громахського зАоров'я, Університет штату Имінойс, Чикаго, США
}

Стаття представляє огляд літератури. $з$ надання інформації щодо створення та впровадження плану оцінювання міжнародного дослідницького консорціуму.

Співробітництво різних дослідників, незважаючи на міжнародні кордони, - посилення можливостей спілкування та обміну даними переважило усі найбільші сподівання вчених. Використовуючи комп'ютерні мережі можна 3 легкістю зосереджуватися на глобальних проблемах здоров'я через створення консорціумів, що дозволяє об'єднувати досягнення дослідницької діяльності різних країн.

По мірі розвитку сумісних зусиль $є$ потреба у двох типах оцінювання. Вони мають бути сфокусовані на результатах наукових проектів, з якими працюють консорціуми; кожен проект оцінюється в тій мірі, у якій були досягнути цілі, а також залежно від успішності розповсюдження зусиль та майбутньої дослідницької активності. $€$ також необхідність у встановленні стратегії оцінювання для визначення самого консорціуму; у цій статті автори інформують про зусилля, які були надані для оцінювання дослідницьких консорціумів.

Університет штату Іллінойс в Чикаго та партнери - Інститут медицини праці НАМН України, Інститут гігієни і медичної екології імені О. М. Марзєєва НАМН України, Інститут педіатрії, акушерства і гінекології НАМН України, Інститут ендокринології та обміну речовин імені В. П. Комісаренка НАМН України, Національний науковий центр радіаційної медицини НАМН України розпочали планування створення міжнародного дослідницького консорціуму для вирішення питань енергобезпеки та захисту здоров'я в Україні. Підтримку у плануванні такого Центру з глобальних проблем медицини довкілля та професійного здоров'я (GEO Hеalth Hub)) буде налавати Національний центр імені Фогарті Національного інституту здоров'я США. Оцінка діяльності буде важливим компонентом у розвитку GEO Health Hub.

Ключові слова: міжнародний дослідницький консорціум, програма оцінювання, логічна модель, Центр з глобальннх проблем медицини довкілля і професійного здоров'я 